\title{
HISTORICALLY ACTIVE VOLCANOES OF ALASKA REFERENCE DECK
}

\author{
Cameron, C.E., Hendricks, K.A., and Nye, C.J.
}

IC 59 v.2 is an unusual publication; it is in the format of playing cards! Each full-color card provides the location and photo of a historically active volcano and up to four icons describing its historical activity. The icons represent characteristics of the volcano, such as a documented eruption, fumaroles, deformation, or earthquake swarms; a legend card is provided. The IC 59 playing card deck was originally released in 2009 when AVO staff noticed the amusing coincidence of exactly 52 historically active volcanoes in Alaska. Since 2009, we've observed previously undocumented persistent, hot fumaroles at Tana and Herbert volcanoes. Luckily, with a little help from the jokers, we can still fit all of the historically active volcanoes in Alaska on a single card deck. We hope our users have fun while learning about Alaska's active volcanoes.

To purchase: http://doi.org/10.14509/29738

The 54* volcanoes displayed on these playing cards meet at least one of the criteria since 1700 CE (Cameron and Schaefer, 2016). These are illustrated by the icons below.

*Gilbert's fumaroles have not been observed in recent years and Gilbert may be removed from future versions of this list. In 2014 and 2015, fieldwork at Tana and Herbert revealed the presence of high-temperature fumaroles (C. Neal and K. Nicolaysen, personal communication, 2016). Although we do not have decades of observation at Tana or Herbert, they have been added to the historically active list.

\section{ACTIVITY ICONS}

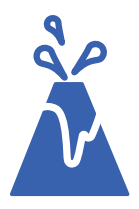

Documented, unquestioned eruption. If a volcano has both documented and suspected eruptions, only the solid symbol is displayed on the card.

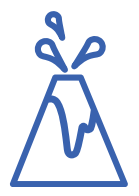

Suspected eruption. Often an eruption documented in a historical account with very little information. Current geologic knowledge must not contradict the eruption account.

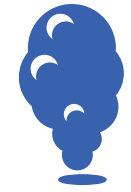

Fumaroles above, at, or near the boiling point. If a volcano has both boiling-point or superheated fumaroles and fumaroles of unknown temperature, only the solid symbol is displayed.

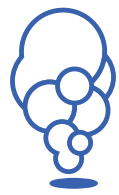

Fumaroles of unknown temperature. This symbol is displayed on the card if the volcano has fumaroles, but the temperature of the fumaroles is not known to be near, at, or above boiling point.

Significant, measured, volcanic-related, deformation (changes to a volcano's ground surface elevation due to magma movement).
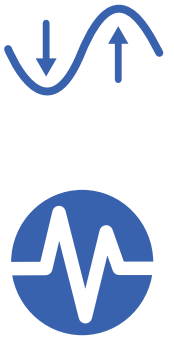

Documented earthquake swarm with strongly suspected volcanic cause.

\section{A NOTE ON ASSIGNING VOLCANOES TO CARDS}

One useful way to subdivide Aleutian Arc volcanoes is on the basis of their geochemistry, specifically whether they are tholeiitic or calcalkaline. In the tholeiitic magma series, the ratio of iron to magnesium increases with increasing silica; in the calcalkaline magma series, the ratio of iron to magnesium stays fairly constant with increasing silica. The two magma series arise from fundamentally different processes governing magma production and evolution, and individual volcanoes generally lie on a continuum between tholeiitic and calcalkaline end members. Tholeiitic volcanoes are typically large in volume, and composed of lavas with few phenocrysts (larger crystals). Calcalkaline volcanoes are typically small in volume and composed of lavas with abundant phenocrysts.

In this deck spades are the most tholeiitic volcanoes, and hearts the most calcalkaline. Clubs represent transitional tholeiitic volcanoes and diamonds are transitional calcalkaline volcanoes. Within each suit, volcanoes are ranked by how well they exemplify their magma series and how thoroughly they have been studied. The Jokers (Novarupta and Kasatochi) are dramatically and perplexingly atypical.
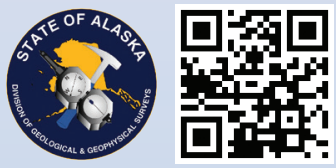

State of Alaska

Department of Natural Resources

Division of Geological \& Geophysical Surveys

3354 College Road, Fairbanks, AK 99709

\section{REFERENCES}

Cameron, C.E., and Schaefer, J.R., 2016, Historically active volcanoes of Alaska: Alaska Division of Geological \& Geophysical Surveys Miscellaneous Publication 133 v.2, 1 sheet, scale 1:3,000,000. http://doi.org/10.14509/20181 
IC 59 v. 2 Historically active volcanoes of Alaska Reference Desk

\section{CAPTIONS}

\begin{tabular}{|c|c|}
\hline Volcano & Caption \\
\hline Back of card & Fireweed blooms at Augustine Volcano, July 2013. Photo by Michelle Coombs, USGS/AVO. \\
\hline Akutan & Akutan volcano, July 2012. Photo by Michelle Coombs, USGS/AVO. \\
\hline Amak & $\begin{array}{l}\text { View of seabirds on Izembek Lagoon, with Amak Island in the distance. Photo by C. Dau, U.S. Fish and Wild- } \\
\text { life Service, October 1, } 1984 .\end{array}$ \\
\hline Amukta & Amukta volcano, on Amukta Island. Photo by U.S. Fish and Wildlife Service, May 31, 1972. \\
\hline Aniakchak & $\begin{array}{l}\text { Aerial view of Aniakchak caldera; Vent Mountain in the foreground and Aniakchak Peak on the rim in the } \\
\text { background. Photo by Game McGimsey, USGS/AVO, June 28, } 1997 .\end{array}$ \\
\hline Augustine & Steam plume from 2006 lava dome at Augustine Volcano, March 27, 2006. Photo by Cyrus Read, USGS/AVO. \\
\hline Bogoslof & $\begin{array}{l}\text { Bogoslof Island, January } 10,2017 . \text { View is to the north, showing an upwelling near the center of the south- } \\
\text { east-facing bay, possibly marking the approximate location of a submarine 2016-2017 eruption vent. Photo } \\
\text { courtesy of Dan Leary. }\end{array}$ \\
\hline Carlisle & $\begin{array}{l}\text { Carlisle volcano, as seen from the summit ridge of Tana volcano. Photo taken August 5, 2015, during the } \\
2015 \text { field season of the Islands of Four Mountains multidisciplinary project, work funded by the National } \\
\text { Science Foundation, the USGS/AVO, and the Keck Geology Consortium. Photo by John Lyons, USGS/AVO. }\end{array}$ \\
\hline Chiginagak & $\begin{array}{l}\text { Summit crater of Chiginagak volcano, September } 27,2010 \text {. In this image, ice and snow are once again ac- } \\
\text { cumulating in the summit crater following the } 2005 \text { heating event and subsequent acid crater lake outflow. } \\
\text { Photo by Janet Schaefer, DGGS/AVO. }\end{array}$ \\
\hline Cleveland & $\begin{array}{l}\text { View of lava dome within Cleveland's summit crater, August 4, 2015, showing concentric rings and radial } \\
\text { fractures in dome surface, surrounding elevated, hot dome core. Photo taken during the } 2015 \text { field season } \\
\text { of the Islands of Four Mountains multidisciplinary project, work funded by the National Science Foundation, } \\
\text { the USGS/AVO, and the Keck Geology Consortium. Photo by John Lyons, USGS/AVO and Joe Schmitt. }\end{array}$ \\
\hline Douglas & Aerial view of the summit crater lake of Mount Douglas. Photo taken June 21, 2010, by Janelle Dyer. \\
\hline Dutton & $\begin{array}{l}\text { View of Mount Dutton, where volcanic seismic swarms were recorded during } 1984 \text { and } 1985 . \text { Photo by M. } \\
\text { Elizabeth Yount, USGS, June 30,1986. }\end{array}$ \\
\hline $\begin{array}{l}\text { Emmons Lake } \\
\text { Volcanic Center }\end{array}$ & $\begin{array}{l}\text { West side of Emmons caldera and Emmons Lake. Cinder cone and lava flows of late Holocene age are visi- } \\
\text { ble in the center left of photo. Photo by Chris Waythomas, USGS/AVO, July 23, } 2017 .\end{array}$ \\
\hline Fisher & $\begin{array}{l}\text { Fisher Caldera, looking northwest from the south caldera rim, across the caldera floor, to the drainage of } \\
\text { Turquoise Lake. Eickelberg Peak is in the background on the right. Photo courtesy of Pete Stelling, } 2000 .\end{array}$ \\
\hline Fourpeaked & Gas emission from Fourpeaked volcano, February 2, 2007. Photo courtesy of Bob Shavelson. \\
\hline Gareloi & $\begin{array}{l}\text { Gareloi Volcano, in the western Aleutian Islands, Alaska. Leveed lava flows from a } 1980 \text { s eruption drape the } \\
\text { south flank of the southern summit crater. The white zone on the crater headwall is an extensive fumarole } \\
\text { field. Photo by Game McGimsey, USGS/AVO, September 25, } 2003 \text {. }\end{array}$ \\
\hline Gilbert & $\begin{array}{l}\text { Mount Gilbert, a little-studied volcano, forms the northern part of Akun Island. Active fumaroles were docu- } \\
\text { mented in the early 1900s. Photo courtesy of Chris Nye, DGGS/AVO, May 10, } 1994 .\end{array}$ \\
\hline Great Sitkin & Aerial view of Great Sitkin volcano, September 8, 2011. Photograph courtesy of Burke Mees. \\
\hline Griggs & $\begin{array}{l}\text { Mount Griggs, the highest peak in Katmai National Park and Preserve. Photo courtesy of Celso Reyes, June } \\
2003 .\end{array}$ \\
\hline Herbert & $\begin{array}{l}\text { Herbert Volcano, July 29, } 2014 \text {. Herbert is a small, island volcano within the "Islands of Four Mountains" } \\
\text { group of the central Aleutian Islands. Photo by Pavel Izbekov, UAFGI/AVO. }\end{array}$ \\
\hline Iliamna & $\begin{array}{l}\text { Iliamna Volcano, viewed from the east. The Red Glacier is in the foreground. Photo by Cyrus Read, USGS/ } \\
\text { AVO, September } 14,2013 .\end{array}$ \\
\hline Kagamil & $\begin{array}{l}\text { View of Kagamil Volcano from the south. White and reddish patches mark active fumarole areas low on the } \\
\text { southern flank. Photo by Steve Smith, August 5, } 2003 .\end{array}$ \\
\hline Kanaga & $\begin{array}{l}\text { Kanaga Volcano, seen from the east, with blocky } 1906 \text { lava flow. Photo by Michelle Coombs, USGS/AVO, } \\
\text { September 20, } 2015 .\end{array}$ \\
\hline Kasatochi & Aerial view of Kasatochi volcano, August 28, 2011. Photograph courtesy of Burke Mees. \\
\hline Katmai & $\begin{array}{l}\text { View from the west rim of the } 4.2-\text { by } 2.5-\mathrm{km} \text { Katmai collapse caldera, which formed in 1912. Photo by Game } \\
\text { McGimsey, USGS/AVO, July 16, } 1990 .\end{array}$ \\
\hline
\end{tabular}




\begin{tabular}{|c|c|}
\hline Volcano & Caption \\
\hline Kiska & Kiska Volcano, on the northern end of Kiska Island. Photo courtesy of Roger Clifford, November 2012. \\
\hline Kliuchef & $\begin{array}{l}\text { View of a satellite vent on the northeast flank of Kliuchef volcano. Photo by Game McGimsey, USGS/AVO, } \\
\text { July } 14,2004 \text {. }\end{array}$ \\
\hline Korovin & $\begin{array}{l}\text { Looking south-southwest, volcanic debris mantles the upper slopes of Korovin's active south crater in the } \\
\text { foreground. Photo by Game McGimsey, USGS/AVO, July 14, } 2004 .\end{array}$ \\
\hline Kukak & Active fumaroles on Kukak Volcano. Photo by Judy Fierstein, USGS, July 31, 1999. \\
\hline Kupreanof & $\begin{array}{l}\text { Mount Kupreanof and its active fumarole field, visible in center-right of photo. Photo by Tom Miller, USGS/ } \\
\text { AVO, June } 30,1973 .\end{array}$ \\
\hline Little Sitkin & Little Sitkin volcano, November 2012. Photo courtesy of Roger Clifford. \\
\hline Mageik & Mount Mageik at sunset, viewed from Baked Mountain, June 22, 2007. Photo courtesy of Mariah Tilman. \\
\hline Makushin & Fumaroles at the summit of Makushin Volcano, July 21, 2017. Photo by Cyrus Read, USGS/AVO. \\
\hline Martin & $\begin{array}{l}\text { Algae colors snow pink on the flanks of Mount Martin, in the foreground, and Mount Mageik, in the back- } \\
\text { ground. Photo by Cyrus Read, USGS/AVO, August 26, } 2006 .\end{array}$ \\
\hline Novarupta & $\begin{array}{l}\text { Aerial view of } 80-\mathrm{m} \text { ( } 260 \text {-ft)-high Novarupta, a blocky rhyolite lava dome that marks the vent for the } 1912 \\
\text { eruption that created the Valley of Ten Thousand Smokes in Katmai National Park and Preserve. This eruption } \\
\text { was the most voluminous on Earth in the 20th century, ejecting nearly } 30 \text { cubic kilometers ( } 7 \text { cubic miles) } \\
\text { of material in } 60 \text { hours. Falling Mountain, a lava dome truncated by the } 1912 \text { eruption, is visible behind the } \\
\text { Novarupta dome; snow-capped Mount Mageik volcano can be seen at top of the photograph. Photograph } \\
\text { by Tom Miller, USGS, June, } 1979 \text {. }\end{array}$ \\
\hline Okmok & $\begin{array}{l}\text { Okmok Volcano in eruption, August 2, 2008. This eruption created a new intracaldera cone, called Ahma- } \\
\text { nilix, an Atkan dialect name meaning "surprise." View from the northeast of Cone D, within Okmok Caldera. } \\
\text { Photo by Janet Schaefer, DGGS/AVO. }\end{array}$ \\
\hline Pavlof & $\begin{array}{l}\text { A spectacular view to the northeast of the Pavlof eruption taken at 20,000 feet on March 28, 2016, by the } \\
\text { U.S. Coast Guard. Lieutenant Commander Nahshon Almandmoss was the Aircraft Commander. Petty Officer } \\
\text { Austin Torres was the flight engineer. All photos were taken from Coast Guard 1713, a HC-130H Hercules } \\
\text { based at Air Station Kodiak. }\end{array}$ \\
\hline Recheshnoi & Mount Recheshnoi's east flank, on Umnak Island. Photo by Christina Neal, USGS/AVO, August 1, 2003. \\
\hline Redoubt & $\begin{array}{l}\text { Redoubt Volcano, viewed from the northwest following the April 4, } 2009 \text { eruption. Steam rises from the } \\
\text { summit crater, pyroclastic flow and surge deposits drape the flanks, and lahar deposits cover the Drift River } \\
\text { Valley. Photo by Game McGimsey, USGS/AVO. }\end{array}$ \\
\hline Seguam & $\begin{array}{l}\text { View of Pyre Peak, the site of Seguam Island's most recent eruptions, and its recent lava flows. Photo courte- } \\
\text { sy of Brad Singer, University of Wisconsin-Madison, } 2004 .\end{array}$ \\
\hline Segula & Segula Peak, November 2012. Photo courtesy of Roger Clifford. \\
\hline Semisopochnoi & $\begin{array}{l}\text { Semisopochoi Island, with the three cones of Mount Cerberus in the foreground and Fenner Lake behind } \\
\text { them. The snow-capped feature in the upper left is Anvil Peak. Photo courtesy of Roger Clifford, November } \\
2012 \text {. }\end{array}$ \\
\hline Shishaldin & Shishaldin Volcano, August 18, 2015. Photo by Cindy Werner, USGS. \\
\hline Snowy & View of Snowy Mountain. Photo by Judy Fierstein, USGS, August 4, 2003. \\
\hline Spurr & $\begin{array}{l}\text { View of Mount Spurr and its flank vent, Crater Peak, looking north. Photo by Game McGimsey, USGS/AVO, } \\
\text { September 16, } 2007 .\end{array}$ \\
\hline Tana & $\begin{array}{l}\text { Hydrothermal alteration and the eastern summit of Tana volcano. Photo taken August 5, 2015, during the } \\
2015 \text { field season of the Islands of Four Mountains multidisciplinary project, work funded by the National } \\
\text { Science Foundation, the USGS/AVO, and the Keck Geology Consortium. Photo by John Lyons, USGS/AVO. }\end{array}$ \\
\hline Tanaga & Summer sunrise behind Tanaga Volcano, August 5, 2013. Photo courtesy of lan Jones. \\
\hline Trident & $\begin{array}{l}\text { Trident Volcano with early morning sunlight, as seen from Baked Mountain. Photo by Mariah Tilman, June } \\
20,2007 .\end{array}$ \\
\hline
\end{tabular}




\begin{tabular}{|c|c|}
\hline Volcano & Caption \\
\hline Ugashik-Peulik & Ugashik Caldera, viewed from the north. Photo by Cyrus Read, USGS/AVO, June 22, 2006. \\
\hline Ukinrek Maars & $\begin{array}{l}\text { One of the two maars formed during the } 1977 \text { eruption at Ukinrek Maars. Photo by Chris Nye, DGGS/AVO, } \\
\text { May 8, } 1994 .\end{array}$ \\
\hline Veniaminof & $\begin{array}{l}\text { Veniaminof volcano in eruption, August 18, 2013. Pulses of ash and ballistics erupt from the intracaldera } \\
\text { cinder cone. Two streams of lava flow down the east flank into an ice cauldron to produce roiling steam } \\
\text { clouds. The lava flows are pouring from vents located below the crater rim, the highest (left lava flow in this } \\
\text { image) of which likely marks the level of a lava lake within the cone. Photo taken by Game McGimsey, AVO/ } \\
\text { USGS. This overflight of Veniaminof was co-sponsored by the National Geographic Society. Photo by Game } \\
\text { McGimsey, USGS/AVO. }\end{array}$ \\
\hline Vsevidof & $\begin{array}{l}\text { Mount Vsevidof with fresh snowfall near the summit, and a light dusting of ash on its lower snowfields from } \\
\text { the July-August } 2008 \text { eruption of nearby Mount Okmok. Photo courtesy of Pathfinder Aviation, October } 8 \text {, } \\
2008 .\end{array}$ \\
\hline Westdahl & $\begin{array}{l}\text { Westdahl Peak's summit. The Westdahl group of volcanoes includes Westdahl, the site of historical erup- } \\
\text { tions, Faris Peak, Pogromni, and Pogromni's Sister. Photo by Cyrus Read, USGS/AVO, August 1, } 2008 .\end{array}$ \\
\hline Wrangell & $\begin{array}{l}\text { Two small plumes rise from summit fumaroles on Mt. Wrangell, March 15, 2010. Photo by Game McGimsey, } \\
\text { USGS/AVO. }\end{array}$ \\
\hline Yunaska & $\begin{array}{l}\text { A view of a ridge on Yunaska Island, looking west. The ridge is formed of four coalescing volcanoes; fore- } \\
\text { ground knobs are remnants of an older volcano called Middle Mountain. Photo courtesy of James Myers, } \\
\text { July } 1992 .\end{array}$ \\
\hline Box & $\begin{array}{l}\text { Steaming Pavlof Volcano (left) and Pavlof Sister (right), as viewed from the west shore of Unga Island. Photo } \\
\text { courtesy of Carl Schaefer, June 8, } 2017 .\end{array}$ \\
\hline
\end{tabular}

